\title{
Physiological activities of Agrimonia pilosa extract
}

\author{
Hyun-Soo Kim* \\ Department of Food Science and Technology, Jungwon University, Goesan 367-805, Korea
}

\section{짚신나물(Agrimonia pilosa) 추출물의 생리활성}

\author{
김현수* \\ 중원대학교 식품공학과
}

\begin{abstract}
In this study, we investigated the applicability of functional materials by examining various physiological activities with an extract from the Agrimonia pilosa root. The A. pilosa extract showed low cytotoxicity against murine melanoma B16F10 cells. With little or no cytotoxicity at various concentrations, the $A$. pilos $a$ extract showed high levels of DPPH radical scavenging activity (ID $50,20.70 \mathrm{mg} / \mathrm{L}$ ) and anti-microbial activity against Bacillus subtilis, Escherichia coli, and Candida albicans. In particular, it had a high level of anti-microbial activities against Gram-positive bacteria. These results suggest that the $A$. pilosa extract can be used as a natural preservative. It also showed inhibition of tyrosinase activity (ID ${ }_{50}, 90.18 \mathrm{mg} / \mathrm{L}$ ), as does kojic acid $\left(\mathrm{ID}_{50}, 89.13 \mathrm{mg} / \mathrm{L}\right)$, and especially, a higher decrease in melanin content $\left(\right.$ (D $_{50}, 62.5 \mathrm{mg} / \mathrm{L}$ ) than the arbutin level $\left(\mathrm{ID}_{50}, 100.7 \mathrm{mg} / \mathrm{L}\right.$ ) as a positive control. These findings suggest that the $A$. pilosa extract inhibits melanin synthesis by suppressing the intracellular tyrosinase expression. These results indicate that the $A$. pilosa extract may be an effective material for functional cosmetics, such as skin whitening materials.
\end{abstract}

Key words : Agrimonia pilosa, antioxidant, antimicrobial activity, melanin, tyrosinase

\section{서 론}

짚신나물(Agrimonia pilosa)은 한국·일본·중국·인도 등 지에 분포하는 여러해살이풀이다. 생육환경은 토양의 비옥 도에 관계없이 양지 혹은 반그늘에서 자란다. 키는 30 100 $\mathrm{cm}$ 정도이고, 잎은 긴 타원형이며 길이가 $3 \sim 6 \mathrm{~cm}$, 폭이 $1.5 \sim 3.5 \mathrm{~cm}$ 로 어긋나고 표면은 녹색이며 양면에 털이 있다. 꽃은 황색으로 길이가 $10 \sim 20 \mathrm{~cm}$ 이며 원줄기 끝과 가지 끝에 달린다. 열매는 8 9월경에 달리고 윗부분에 갈고리와 같은 가시들이 많이 나 있는 특성을 나타내며, 어린잎을 식용으로 하고 전초는 한방에서 약용으로서 사용되고 있다 (1). 짚신나물은 다양한 생리적 기능이 알려져 있으며 우선

*Corresponding author. E-mail : hyun1006@jwu.ac.kr Phone : 82-43-830-8616, Fax : 82-43-830-8679

Received 22 January 2015; Revised 10 March 2015; Accepted 11 March 2015.

Copyright (c) The Korean Society of Food Preservation. All rights reserved.
풍부하게 함유되어 있는 폴리페놀 성분에 의한 항산화 활성 이 보고(2,3)되었으며, 종양억제 활성(4) 및 항바이러스 활 성(5), 항균작용(6)에 대한 연구도 이루어져 있다. 또한, 당 뇨를 유발한 쥐에서 짚신나물 추출물을 투여했을 때 혈당개 선효과를 확인(7)하였으며, lipopolysaccharide로 활성화된 RAW 264.7 세포에서 짚신나물 추출물이 염증유발 사이토 카인 및 inducible nitric oxide synthase(iNOS)와 reactive oxygen species(ROS)의 발현을 억제하여 항염효과가 있는 것으로 보고되었다(8).

현대사회에서 증가하는 건조 환경 및 사회적 스트레스 등으로 악화되고 있는 피부장벽손상(건조피부, 민감성피 부, 노인성 건성피부, 아토피피부)을 개선하기 위한 천연소 재 개발에 대한 연구가 많이 진행되고 있으며 특히, 하얀색 피부를 선호하는 아시아권 여성들을 중심으로 미백효과를 볼 수 있는 소재개발에 대한 관심이 증가하고 있다(9). 피부 색은 멜라닌 생성세포가 합성하는 멜라닌(melanin)의 양과 종류에 따라 결정되며 자외선과 같은 외부자극으로부터 피부를 보호하기 위해 멜라닌 생성을 하게 된다. 그러나 
피부표면에 과도한 멜라닌 합성과 축적은 기미, 주근깨와 같은 과색소 침착 증상이 나타나게 된다(10). 멜라닌 생성은 tyrosinase, tyrosinase related protein-1(TRP-1), TRP-2 효소 에 의해 조절되며 tyrosinase는 구리를 포함한 효소로서 멜 라닌 형성에 중요한 역할을 하고 있다(11). Tyrosinase는 멜라노좀(melanosome)내에서 tyrosine을 산화시켜 DOPA 를 생성하는 tyrosine hydroxylase로서, 또한, DOPA를 산화 시켜 DOPA quinone을 만드는 DOPA oxidase로서 작용하여 멜라닌 중합체를 합성하는 핵심 효소로 작용한다(11). 따라 서 멜라닌 생합성을 억제하여 미백효과를 가져올 수 있는 독성이 없는 천연소재 물질에 대한 개발이 요구되고 있다(12).

본 연구의 재료인 짚신나물( $A$ pilosa)은 어린잎과 전초에 대한 다양한 생리활성의 보고에 따른 기능성 소재 응용가능 성을 기대할 수 있음에도 불구하고 상대적으로 뿌리부분에 대한 생리활성 연구가 부족하며 특히, 미백활성 등 피부개 선 효과를 비롯한 기능성 화장품소재에 활용하기 위한 연구 는 미흡한 실정이다. 따라서 본 연구에서는 짚신나물 뿌리 를 추출한 시료를 가지고 항산화 및 항균활성, 안전성 시험 을 비롯한 생리활성 시험과 미백시험을 비롯한 피부효능 개선 시험을 조사하여 기능성 화장품 소재로서의 개발 가능 성을 검토하고자 하였다.

\section{재료 및 방법}

\section{실험재료}

짚신나물 $(A$ pilosa $)$ 뿌리에 대한 추출물은 국립원예특작 과학원 인삼특작부 추출물은행에서 분양받은 시료를 실험 에 이용하였으며 제시된 추출방법은 시료 $200 \mathrm{~g}$ 에 $70 \%$ 에탄올 $1 \mathrm{~L}$ 를 첨가하여 실온에서 2 일간 2회 추출하고 이를 여과, 감압농축, 동결건조 하는 것이다.

\section{세포독성평가}

세포독성 시험은 세포내의 미토콘드리아 탈수소효소에 의해 water soluble tetrazolium salts(WST-1)에서 불용성의 formazan결정으로 변환되는 원리를 이용한다(13). Formazan 이 많이 생성될수록 세포 활성이 커지는 것을 의미한다. Formazan은 dimethly sulfoxide(DMSO)에 녹아서 보라색 빛 을 띄는데 spectrophotometer로 $540 \mathrm{~nm}$ 파장에서 $\mathrm{OD}$ 값을 재어서 정량한다. 미국 세포주은행(ATCC)에서 분양 받은 멜라노마 세포(murine melanoma B16F10)를 10\% 우태아 혈청(fetal bovine serum, FBS, Gibco, USA)이 포함된 Dulbecco's Modified Eagle's medium(DMEM)에서 배양하 고 24 well plate에 $2 \times 10^{4}$ cells/well 의 농도로 세포를 접종한 후, $37^{\circ} \mathrm{C}, 5 \% \mathrm{CO}_{2}$ 조건에서 배양한다. 이후 배양세포에 추출물을 농도별로 처리하고 72 시간 배양하였다. 결과는 $\%$ 로 환산하였다. 각 처리농도에서의 결과 수치로 $50 \%$ 저해
농도 $\left(\mathrm{ID}_{50}\right)$ 을 계산하여 세포 독성 정도를 표현하였다.

\section{항산화력 측정}

DPPH radical 소거능 실험은 DPPH(1,1-diphenyl-2-picryl hydrazyl, Sigma Chemical Co., St. Louis, MO, USA)에 의한 전자공여능(electron donating ability, EDA)을 측정하였다 (14). 즉, $0.2 \mathrm{mM}$ 의 $\mathrm{DPPH}$ 용액 $0.8 \mathrm{~mL}$ 에 식물추출물 시료 $0.2 \mathrm{~mL}$ 를 첨가하여 혼합한 다음 실온에서 30 분간 반응시킨 후 $517 \mathrm{~nm}$ 에서 흡광도를 측정하였다. 항산화력은 [1-(시료 첨가구의 흡광도/무첨가구의 흡광도) $\times 100$ 의 계산식에 의 해 전자공여능(\%)을 구하였으며, 대조구는 시료 대신 메탄 올을 첨가하였고, positive control로 L-ascorbic acid를 사용 하였다. 각 처리농도에서의 결과 수치로 $50 \%$ 저해 농도 $\left(\mathrm{ID}_{50}\right)$ 를 계산하여 $\mathrm{DPPH}$ 소거 활성 정도를 표현하였다.

\section{항균활성 측정}

항균효과는 agar disc diffusion방법(15)을 이용하여 측정 하였다. 즉, 시료액을 $0.22 \mu \mathrm{m}$ membrane filter로 여과하여 제균하고 멸균된 paper disc에 흡수시킨 후 시험용 평판배지 표면에 놓아 밀착시키고 각 균주(B. subtilis, E. coli, C. albicans) 의 배양조건에 따라 24 48시간 동안 배양한 다음 paper disc 주위의 clear zone 및 inhibition zone의 크기로 항균성을 조사하였다. 또한, 시간별로 항균작용이 어떤 변 화를 보이는지 알아보기 위해 time-curve를 작성하였다. 각 각 균주 배양액에 짚신나물 뿌리 추출물 최종농도가 100 $\mathrm{mg} / \mathrm{L}$ 이 되도록 처리한 후, 일정 시간별로 배양액을 채취하 였다. 채취한 배양액을 십진희석법으로 희석하고 각각 균 주평판배지에 접종하여 배양한 후, 생성되는 군락(colony) 의 수를 측정하고 $\mathrm{CFU} / \mathrm{mL}$ 로 환산하였다.

\section{Tyrosinase 저해활성측정}

Melanin 합성에 중요한 단백질인 tyrosinase 저해활성 측

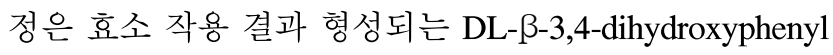
alanine(DOPA) chrome을 비색법에 의해 측정하는 Masamoto 등의 방법(16)을 변형하여 측정하였다. 기질로서 $5 \mathrm{mM}$ DL-DOPA 용액 $0.2 \mathrm{~mL}, 0.1 \mathrm{M}$ 인산완충용액 $(\mathrm{pH}$ 6.8) 0.2 $\mathrm{mL}$ 및 시료용액 $0.5 \mathrm{~mL}$ 의 혼합액에 mushroom tyrosinase (Sigma Chemical CO., 250 unit/mL) $0.1 \mathrm{~mL}$ 을 첨가하여 $37^{\circ} \mathrm{C}$ 에서 10 분간 반응시킨 다음 $475 \mathrm{~nm}$ 파장에서 흡광도를 측정하고 아래 식에 따라 tyrosinase 저해활성을 산출하였 다. 각 처리농도에서의 결과 수치로 $50 \%$ 저해 농도 $\left(\mathrm{ID}_{50}\right)$ 을 계산하여 tyrosinase 저해 활성 정도를 표현하였다.

Tyrosinase 저해 활성(\%)=1-(시료첨가구의 흡광도/대조 구의 흡광도) $\times 100$

멜라닌 생성 저해 측정

멜라닌 정량은 Hosoi 등의 방법(17)을 변형하여 사용하 
였다. 24 well plate에 $2 \times 10^{4}$ cells/well로 멜라노마 세포를 분주하였고, 3-isobutyl-1- methylxanthine(IBMX)으로 멜라 난 생성을 유도한 후, 상기 세포독성 실험에서 관찰된 짚신 나물 추출물시료 농도를 처리하고 48 시간 동안 $37^{\circ} \mathrm{C} \mathrm{CO}_{2}$ 배양기에서 배양하였다. 세포를 수집하여 세포수를 측정하 고, $1,200 \mathrm{rpm}$ 에서 5 분간 원심 분리하여 침전한 후, $1 \mathrm{~mL}$ homogenization buffer(50 mM sodium phosphate $\mathrm{pH} 6.5,1 \%$ Triton X-100, $2 \mathrm{mM}$ PMSF)로 용해시켰다. 여기서 얻은 pellet에 $1 \mathrm{~N} \mathrm{NaOH}(10 \% \mathrm{DMSO}) 200 \mu \mathrm{L}$ 를 첨가하고 vortex 후 $405 \mathrm{~nm}$ 에서 흡광도값을 측정하였다. 추출물을 처리하지 않은 시료군을 대조군으로 하고 미백제로 알려진 합성물질 인 arbutin을 표준시료로 사용하였으며 결과는 \%로 환산하 였다. 각 처리농도에서의 결과 수치로 $50 \%$ 멜라닌 생성 저해 농도 $\left(\mathrm{ID}_{50}\right)$ 을 계산하여 멜라닌 생성 저해 활성을 표현 하였다.

\section{통계처리}

모든 실험은 독립적으로 3회 반복 시행하고 실험결과는 평균표준편차로 표기하였으며, 통계적 유의성은 Student's $\mathrm{t}$-test로 하였으며 $\mathrm{p}<0.05$ 일 때 통계적으로 유의하다고 판단 하였다.

\section{결과 및 고찰}

\section{짚신나물 추출물의 세포독성시험}

멜라노마 세포에 짚신나물 뿌리 추출물 $(A$ pilosa extract, APE) $250 \mathrm{mg} / \mathrm{L}, 500 \mathrm{mg} / \mathrm{L}, 750 \mathrm{mg} / \mathrm{L}, 1,000 \mathrm{mg} / \mathrm{L}$ 의 농도로 처리한 후, WST-1 분석법(13)을 이용하여 세포독성을 측정 하였다(Fig. 1). 대조군과 대비하여 $250 \mathrm{mg} / \mathrm{L}, 500 \mathrm{mg} / \mathrm{L}$, $750 \mathrm{mg} / \mathrm{L}, 1,000 \mathrm{mg} / \mathrm{L}$ 의 $\mathrm{APE}$ 농도에서 각각 $0 \%, 0.59 \%$,

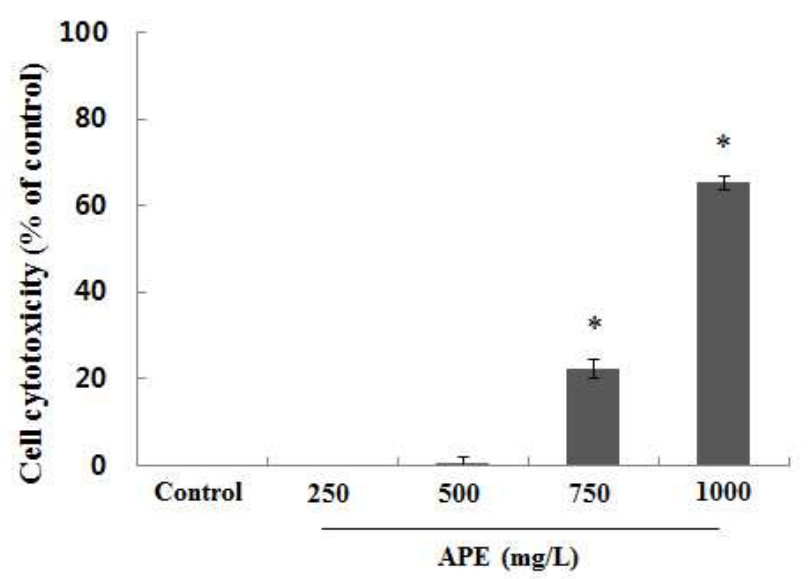

Fig. 1. Cell cytotoxicity of the Agrimonia pilosa extract (APE) on the murine melanoma B16F10 cell.

The values are presented as mean \pm SEM. Differences were considered statistically significant when ${ }^{*} \mathrm{p}<0.05,{ }^{*} \mathrm{p}<0.01$.
$22.45 \%, 65.46 \%$ 세포독성을 나타냈으며, $50 \%$ 세포독성을 나타내는 농도 $\left(\mathrm{ID}_{50}\right)$ 는 $881.11 \mathrm{mg} / \mathrm{L}$ 로 나타났다. 따라서 이 후의 실험은 독성이 거의 없는 $500 \mathrm{mg} / \mathrm{L}$ 이하의 농도에서 진행하였으며 멜라닌 생성 억제효과로서 보고된 백합뿌리 추출물(18)의 경우는 세포독성이 거의 없는 농도가 100 $\mathrm{mg} / \mathrm{L}$ 이하인 것과 비교하였을 때 천연물시료 중 독성이 없는 더 안전한 물질로 판단된다.

\section{짚신나물 추출물의 DPPH 라디칼 소거 활성}

짚신나물 뿌리 추출물에 대해서 대조구로 아스코르브산 (ascorbic acid)를 이용하여 DPPH 라디칼 소거 활성법(14)으 로 항산화 활성을 측정하였다. 추출물 시료와 대조구 시료 를 각각 $10 \mathrm{mg} / \mathrm{L}, 50 \mathrm{mg} / \mathrm{L}, 100 \mathrm{mg} / \mathrm{L}$ 의 농도로 제조하여 $\mathrm{DPPH}$ 라디칼 소거활성을 측정한 결과 (Fig. 2), APE 농도 $10 \mathrm{mg} / \mathrm{L}, 50 \mathrm{mg} / \mathrm{L}$ 경우 $56.8 \%, 88.7 \%$ 의 소거능 활성을 보였으며 따라서 추출물 시료의 농도가 증가할수록 라디칼 소거능 활성이 증가하였다. APE 각각에 대한 같은 시료농 도 대조구인 아스코르브산과 비교 하였을 때는 소거활성이 다소 낮았으나, $100 \mathrm{mg} / \mathrm{L}$ 의 추출물 농도에서는 대조구와 거의 같은 라디칼 소거활성을 보였다(91.3\%). 또한, $\mathrm{APE}$ 의 경우, $50 \%$ 라디칼 소거활성 농도는 $20.70 \mathrm{mg} / \mathrm{L}$ 였으며 대조 군 표준시료인 비타민 C(ascorbic acid)의 경우는 $5.65 \mathrm{mg} / \mathrm{L}$ 였다. 또한, 기존 보고된 짚신나물 잎 열수추출물의 $50 \%$ 라디칼 소거활성 농도 $13 \mathrm{mg} / \mathrm{L}$ 과 비교해 볼 때 $(2,3)$ 짚신나 물 뿌리 부분의 추출물에도 항산화 활성을 나타내는 물질이 함유되어 있음을 의미하며 항산화 소재로서의 가능성을 지니고 있음을 확인할 수 있다.

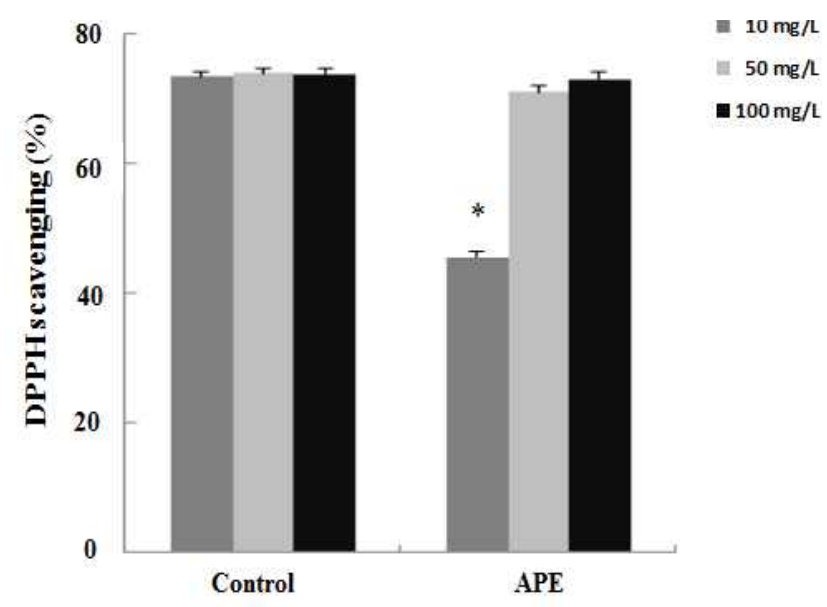

Fig. 2. DPPH radical scavenging activities of the Agrimonia pilosa extract (APE). Ascorbic acid was used as a positive control.

The values are presented as mean \pm SEM. Differences were considered statistically significant when ${ }^{*} \mathrm{p}<0.05$.

\section{짚신나물 추출물의 항균 활성}

짚신나물 뿌리 추출물에 대한 항균활성 측정은 디스크 확산법(disc diffusion method)을 이용하였다. DMSO $10 \mu \mathrm{L}$ 
에 $10 \mathrm{mg}$ 이 되도록 만든 후, DMSO만을 함유한 disc를 대조 군으로 하고, 각 농도의 시료액을 포함한 disc를 시험균으로 그람양성균 대표로서 B. subtilis, 그람음성균 대표로서 $E$. coli, 효모균 대표로서 C. albicans를 균일하게 접종된 배지 위에 올려 놓고 $30^{\circ} \mathrm{C}$ 에서, E. coli 만 $37^{\circ} \mathrm{C}$ 에서 48 시간 동안 배양하여 disc주변의 투명환을 관찰하여 항균활성을 측정 하였다(Fig. 3). 대조군에서는 균의 증식이 억제되지 않았으 나 짚신나물 뿌리 추출물에 대하여는 항균활성이 나타났으 며, 특히, 그람양성균에 대한 항균활성이 가장 높게 나타났 다. 또한, 추출물 시료 최종농도가 $100 \mathrm{mg} / \mathrm{L}$ 가 되도록 처리 한 후, 시간별로 각각 시험군에 대한 항균작용을 알아보기 위해, time curve를 작성하였다(Fig. 3). 대조군의 경우 시간 이 경과함에 따라 균의 증식에 변함이 없었으나 추출물 시료처리 경우는 배양 12 시간 경과 후, B. subtilis, E. coli, C. albicans 각각 대조군에 대하여 $50.5 \%, 40.2 \%, 33.7 \%$ 의 증식 억제가 확인되었다. 즉, 모든 시험균의 증식이 억제됨 을 확인 할 수 있었으며 disc 확산법과 마찬가지로 그람양성 균인 B. subtilis에 대한 증식억제 효과가 가장 높게 나타났 다. 따라서 짚신나물 추출물(APE)은 항균력이 우수하며, 특히 포자를 형성하여 살균이 상대적으로 어려운 그람양성 균에 대한 항균력이 탁월함을 보임으로써 원인균에 대한 천연방부제로서의 소재개발 가능성을 기대할 수 있을 것으 로 생각한다.

\section{짚신나물 추출물의 tyrosinase 저해활성}

Tyrosinase는 구리를 포함한 효소로서 멜라닌 형성에 중 요한 역할을 하고 있다. 이러한 멜라닌 중합체 생합성을 효과적으로 저해하기 위한 tyrosinase 저해활성을 측정하기 위하여 짚신나물 뿌리 추출물에 대한 mushroom유래의

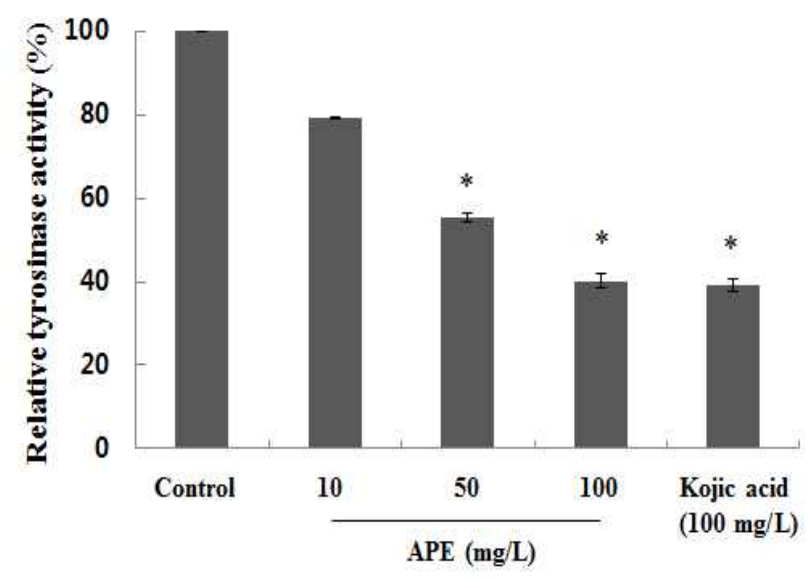

Fig. 4. Inhibitory effect of the Agrimonia pilosa extract (APE) on tyrosinase. The tyrosinase activity assay was performed with mushroom tyrosinase.

The values are presented as mean \pm SEM. Differences were considered statistically significant when ${ }^{\star} p<0.05$.
A

Bacillus subtilis

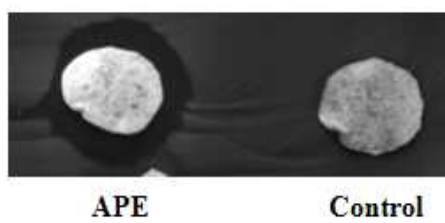

APE

Control
Escherichia coli

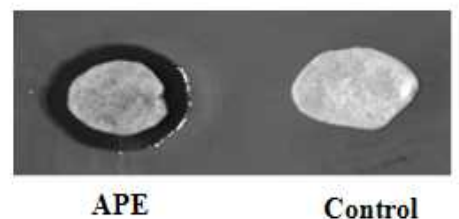

APE
Control

\section{Candida albicans}

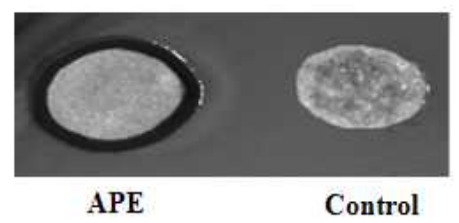

B
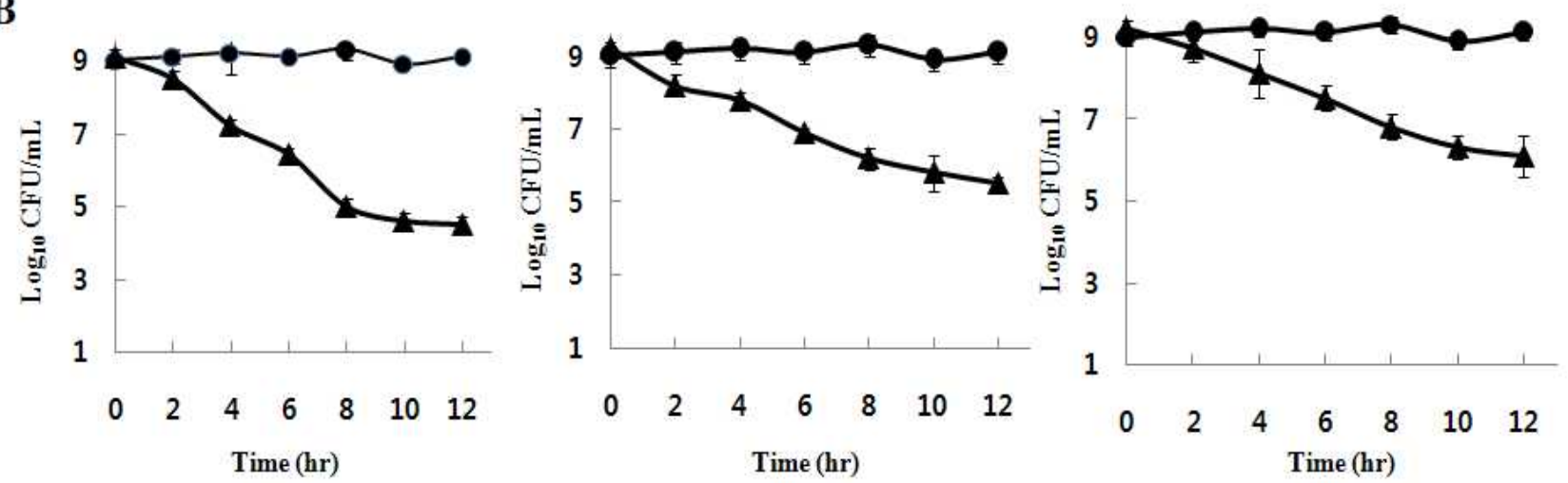

Fig. 3. Anti-microbial effect of the Agrimonia pilosa extract (APE). A clear zone was examined around paper disc.

$10 \%$ DMSO was used as a negative control; B, time-curve of APE against B. subtilis, E. coli and C. albicans. 10\% DMSO was used as a negative control () and APE was dissolved in 10\% DMSO to a final concentration of $100 \mathrm{mg} / \mathrm{L}(\boldsymbol{\Delta})$ 
tyrosinase 저해활성을 관찰하였다(Fig. 4). 추출물시료 10 $\mathrm{mg} / \mathrm{L}, 50 \mathrm{mg} / \mathrm{L}, 100 \mathrm{mg} / \mathrm{L}$ 의 경우, 각각 $20.8 \%, 44.7 \%, 59.8 \%$ 의 tyrosinase 저해활성을 나타내었다. 한편, 미백활성의 표 준시료로서 kojic acid $100 \mathrm{mg} / \mathrm{L}$ 의 경우 $60.8 \%$ 의 저해활성 을 나타내었다. 또한, $\mathrm{APE}$ 의 경우, $50 \%$ tyrosinase 저해활성 농도는 $90.18 \mathrm{mg} / \mathrm{L}$ 였으며 대조군 표준시료인 kojic acid의 경우는 $89.13 \mathrm{mg} / \mathrm{L}$ 임을 고려하면, 짚신나물 뿌리 추출물시 료가 대조군 kojic acid와 비교했을 때도 동일한 수준으로 우수하게 나타났으며 또한, 다른 천연소재 중 우수한 미백 활성 효과로서 보고된 바(19) 있는 녹나무과 추출물 100 $\mathrm{mg} / \mathrm{L}$ 의 경우 $52.8 \%$ tyrosinase 저해활성을 보이는 것과 비 교하였을 때, 향후 미백 기능성 소재로서의 활용 가능성이 매우 높다고 생각된다.

\section{짚신나물 추출물의 멜라닌 생성 저해활성}

짚신나물 뿌리 추출물(APE)에 대한 세포독성 실험 측정 에서 정한 독성이 없는 농도에서 멜라닌 생성 저해 활성을 측정하였다(Fig. 5). 대조군 대비하여 $50 \mathrm{mg} / \mathrm{L}, 100 \mathrm{mg} / \mathrm{L}$, $250 \mathrm{mg} / \mathrm{L}, 500 \mathrm{mg} / \mathrm{L}$ 의 APE 농도에서 각각 $51.7 \%, 72.2 \%$, $91.3 \%, 100 \%$ 의 멜라닌 생성 억제 활성을 확인하였다. 또한, $\mathrm{APE}$ 의 경우, $50 \%$ 멜라닌 저해활성 농도는 $62.5 \mathrm{mg} / \mathrm{L}$ 이였 으며 또한, 대조군 표준시료로서 tyrosinase 경쟁적 저해제 로 작용한다고 알려져 있는(12) arbutin의 경우는 100.7 $\mathrm{mg} / \mathrm{L}$ 임을 고려하면 멜라닌 생성 저해 활성이 매우 우수함 을 의미한다. 즉, 시험재료에 있어서 피부미백효과는 멜라 닌 생성 저해에 따른 tyrosinase 저해효과가 나타나야 한다. 본 연구의 짚신나물 뿌리 추출물(APE)의 경우도 멜라닌 저해 활성이 우수하였으며 이에 따른 tyrosinase 저해활성도

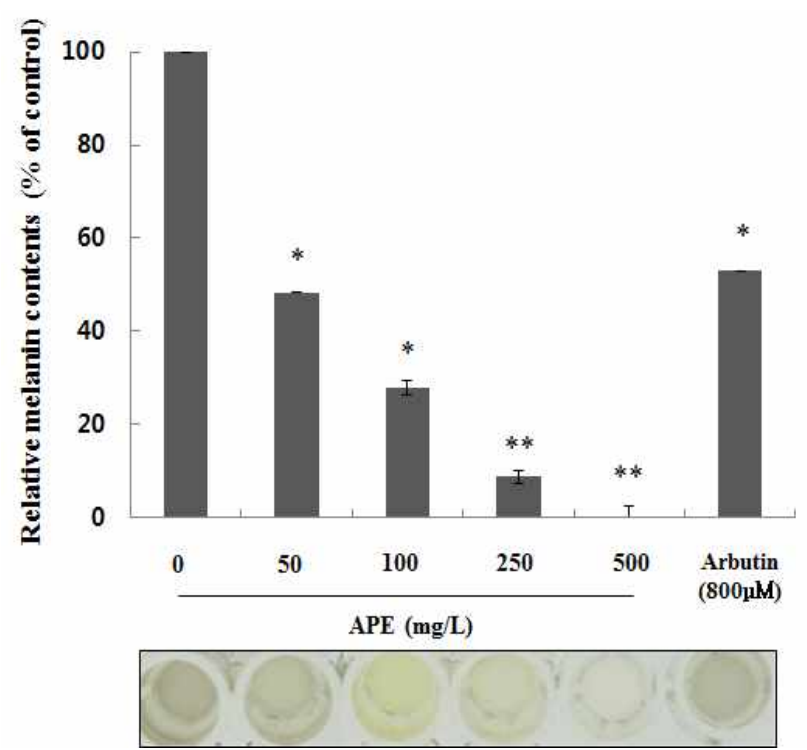

Fig. 5. Anti-melanogenic effects of the Agrimonia pilosa extract (APE). Arbutin was used as a positive control.

Values are presented as mean \pm SEM. Differences were considered statistically significant when ${ }^{*} \mathrm{p}<0.05$, ${ }^{*} \mathrm{p}<0.01$.
높았다. 따라서 짚신나물 뿌리 추출물의 경우, 직접적인 tyrosinase 활성저해에 의한 기작으로 멜라닌 생성이 억제된 것으로 사료된다.

\section{요 약}

본 연구에서 짚신나물( $A$ pilosa)의 뿌리부분에 대한 다양 한 생리활성을 조사하여 기능성소재 응용가능성을 검토하 였다. 짚신나물 뿌리 추출물은 멜라노마 세포에 대하여 낮 은 세포독성을 나타냈다. 세포독성이 거의 없는 농도에서 짚신나물 뿌리 추출물 처리 시 항산화 $\left(\mathrm{ID}_{50}, 20.70 \mathrm{mg} / \mathrm{L}\right)$ 및 항균활성이 매우 우수하게 나타났으며 특히 그람양성세 균에 대한 항균활성이 높았다. 또한, 짚신나물 뿌리 추출물 처리시 높은 tyrosinase 활성저해( $\left.\mathrm{ID}_{50}, 90.18 \mathrm{mg} / \mathrm{L}\right)$ 및 멜라 닌 함량 저하를 보여주었다. 이는 짚신나물 추출물이 세포 내 tyrosinase 발현을 억제시킴으로서 멜라닌 합성을 저해하 는 것으로 판단된다. 이와 같은 결과로 미루어 볼 때 짚신나 무 뿌리 추출물은 피부미빽 소재 등 피부개선 효과를 비롯 한 기능성 화장품에 활용하기 위한 매우 효과적인 재료가 될 수 있다고 판단된다.

\section{감사의 글}

본 연구는 2014년도 산업통상자원부와 한국산업기술진 흥원의 지역특화산업육성사업(R\&D)의 지원(R-0002327) 에 의해 수행되었으며, 국립원예특작과학원 인삼특작부 추 출물은행(과제번호 PJ009629)으로부터 제공받은 추출물을 재료로 사용하였음으로 이에 감사드립니다.

\section{References}

1. Hsu MF, Young JH, Wang JP, Teng CM (1987) Effect of hsien-ho-t'sao (Agrimonia pilosa) on experimental thrombosis in mice. Am J Chin Med, 15, 43-51

2. Zhu L, Tan J, Wang B, He R, Liu Y, Zheng C (2009) Antioxidant activities of aqueous extract from Agrimonia pilosa Ledeb and its fractions. Chem Biodivers, 6, 1716-1726

3. Kato H, Li W, Koike M, Wang Y, Koike K (2010) Phenolic glycosides from Agrimonia pilosa. Phytochem, 71, 1925-1929

4. Koshiura R, Miyamoto K, Ikeya Y, Taguchi H (1985) Antitumor activity of methanol extract from roots of Agrimonia pilosa Ledeb. Japan J Pharmacol, 38, 9-16 
5. Shin WJ, Lee KH, Park MH, Seong BL (2010) Broad-spectrum antiviral effect of Agrimonia pilosa extract on influenza viruses. Microbiol Immunol, 54, 11-19

6. Yamaki M, Kashihara M, Ishiguro K, Takagi S (1989) Antimicrobial principles of Xian he cao (Agrimonia pilosa). Planta Med, 55, 169-170

7. Jung $\mathrm{CH}$, Zhou S, Ding GX, Kim JH, Hong MH, Shin YC, Kim GJ, Ko SG (2006) Anti-hyperglycemic activity of herb extracts on streptozotocin-induced diabetic rats. Biosci Biotechnol Biochem, 70, 2556-2559

8. Jung $\mathrm{CH}$, Kim JH, Park S, Kweon DH, Kim SH, Ko SG (2010) Inhibitory effect of Agrimonia pilosa Ledeb. on inflammation by suppression of iNOS and ROS production. Immunol Invest, 39, 159-170

9. Sohn ES, Kim SW, Kang JS, Lee SP (2004) Technology trend patent information analysis of cosmetic materials derived from natural products. Appl Chem, 8, 466-469

10. Hill HZ, Li W, Xin P, Michell DL (1997) Melanin : a two edged sword ? Pigment Cell Res, 10, 158-161

11. Kobayashi $\mathrm{T}$, Urabe $\mathrm{K}$, Winder AJ, Jimenez-Cervantes C, Imokawa G, Brewington T, Solano F, Garcia-Borron JC, Hearing VJ (1994) Tyrosinase related protein-1 (TRP-1) function as a DHICA oxidase in melanin biosynthesis. EMBO J, 3, 5818-5825

12. Briganti S, Camera E, Picardo M (2003) Chemical and instrumental approaches to treat hyperpigmentation. Pigment Cell Res, 16, 101-110
13. Ranke J, Mölter K, Stock F, Bottin-Weber U, Poczobutt J, Hoffmann J, Ondruschka B, Filser J, Jastorff B (2004) Biological effects of imidazolium ionic liquids with varying chain lengths in acute Vibrio fischeri and WST-1 cell viability assays. Ecotoxicol Environ Saf, 58, 396-404

14. Miliauskas G, Venskutonis PR, van Beek TA (2004) Screening of radical scavenging activity of some medicinal and aromatic plant extracts. Food Chem, 85, 231-237

15. Farag RS (1989) Antimicrobial activity of some Egyptian spice essential oils. J Food Prot, 52, 665-670

16. Masamoto Y, Ando H, Murata Y, Shimoishi Y, Tada M, Takahata K (2003) Mushroom tyrosinase inhibitory activity of esculetin isolated from seeds of Euphorbia lathyris L.. Biosci Biotechnol Biochem, 67, 631-634

17. Hosoi J, Abe E, Suda T, Kuroki T (1985) Regulation of melanin synthesis of B16 mouse melanoma cells by 1 alpha, 25-dihydroxyvitamin D3 and retinoic acid. Cancer Res, 45, 1474-1478

18. Yoon HS, Yang KW, Kim JE, Kim JM, Lee NH, Hyun CG (2014) Hypopigmenting effects of extracts from bulbs of Lilium Oriental Hybrid 'Siberia' in murine B16/F10 melanoma cells. J Korean Soc Food Sci Nutr, 43, 705-711

19. Jin KS, Lee JY, Kwon HJ, Kim BW (2013) Anti-oxidative, anti-inflammatory, and anti-melanogenic activities of Endlicheria anomala extract. Korean J Microbiol Biotechnol, 41, 433-441 